\title{
TRANSLATION AND SCIENCE IN THE LUSO- BRAZILIAN ENLIGHTENMENT: INTERTEXTUALITY IN EPIGRAPHS AND MOTTOES
}

\author{
Alessandra Oliveira Harden $\underline{1}$ \\ 1Universidade de Brasília, Brasília, Distrito Federal, Brasil
}

\begin{abstract}
Researchers working with translation history have been benefiting from information stemming from editorial paratexts, and these elements have also become an acceptable tool for science historians. For both groups of researchers, crucial information concerning intellectual and cultural affiliations can be unveiled by paratexts, taken as evidence of a written work's materiality in a given point in time and space, as well as of the intervention of authors, translators and editors in the way such work is to be interpreted. The revealing role of paratextual elements is even more prominent if one is interested in intertextual connections, which is the case with this paper. Here focus is given to epigraphs and mottoes, in a discussion based on the content of title pages of translations produced within the Luso-Brazilian Enlightenment. Published at the turn of the $18^{\text {th }}$ century in Lisbon and under the supervision of Brazilian-born Friar José Mariano da Conceição Velloso ${ }^{1}$, these translation aimed at the progress of the Portuguese Kingdom through the dissemination of "useful science." Their epigraphs and mottoes are relevant material for translation and science historians alike, as they allow for a deeper understanding of cultural networks decisive to the dissemination of enlightened ideas in Portuguese language.
\end{abstract}

Keywords: Translation history; Science history; Intertextuality; Epigraphs and mottoes; Luso-Brazilian Enlightenment

1 Various spellings have been given in historiography to the Friar's surname: 'Veloso', 'Velozo', 'Velloso' and 'Vellozo'. The form Velloso seems to have been favoured in bibliographical data, reason why it is adopted here. 


\title{
TRADUÇÃO E CIÊNCIA NO ILUMINISMO LUSO- BRASILEIRO: INTERTEXTUALIDADE EM EPÍGRAFES E DIVISAS
}

\begin{abstract}
Resumo: As pesquisas na área de história da tradução há muito têm se beneficiado com a análise dos paratextos editoriais, material que também utilizado nas investigações conduzidas por historiadores da ciência. Nessas áreas, o recurso a esses elementos - marcas tanto da materialidade do texto em determinado contexto temporal e espacial quanto da intervenção de autores, tradutores e editores na interpretação das obras - pode revelar características importantes acerca das filiações intelectuais e culturais desses agentes, em particular se for dada atenção à intertextualidade criada. Nesse sentido, voltado mais especificamente para o exame de epígrafes e divisas, este trabalho apresenta discussão feita com base em material constante em páginas de rosto de traduções produzidas no âmbito do Iluminismo luso-brasileiro. Publicadas na virada do século XVIII em Lisboa sob a coordenação do Frei José Mariano da Conceição Veloso, essas obras tinham o propósito de trazer o progresso ao Reino Português por meio da chamada boa e útil ciência. As epígrafes e divisas nelas encontradas são tema relevante igualmente para a história da tradução e para a história das ciências, pois seu exame permite compreensão mais aprofundada de redes culturais determinantes para a disseminação do ideário iluminista em língua portuguesa
\end{abstract}

Palavras-chave: História da tradução; História da ciência; Intertextualidade; Epígrafes e divisas; Iluminismo luso-brasileiro

\section{Introduction}

With this paper, my aim is to discuss the effect of epigraphs and mottoes in relation to the building and the promotion of an intertextual web which connected Luso-Brazilian translators and scientists and authors of considerable authority. The focus here rests on a very specific phenomenon: "the scientific translation boom" at the turn of the $18^{\text {th }}$ century in Portugal, a unique episode in the history of the Portuguese language and one which was essential for the scientific and technological development of Portugal and Brazil (Wyler 73; Oliveira Harden "Brasileiro tradutor", "Tradução, 
história e Iluminismo"). From the repertoire of translations published within this movement, nine selected works were the source for the epigraphs and mottoes which are the basis of my considerations in this study.

To address this topic, this paper is hopefully organized in a way which allows readers to get acquainted with epistemological and methodological assumptions leading to the conclusions drawn. Therefore, the second section presents brief considerations on aspects shared by translation history and science history, as well as on the key concepts of intertextuality, epigraphs and mottoes. In the third section, one finds a concise overview of the scientific translation boom, necessary for contextualizing the translated works from which were taken the epigraphs and mottoes analysed in the fourth section. This is followed by my final considerations.

\section{Points of contact between translation history and science history}

If no one can be sure of what the process of translating means, there is little doubt that the relationship between the texts involved (one that is the original, the source or the inspiration for a second one, the equivalent, the target or the one which is derivative) is one based on intertextuality, a "a mosaic of quotations" (Kristeva 37) or a conversation of ideas, concepts, aesthetical or ideological values which the readership is able to identify or at least to assume due to information given outside the texts themselves (by editors or critics, for example).

Even though it is more directly associated with the literary realm, the concept of intertextuality has also been turned into an object or a category of analysis in studies linked with scientific texts, especially in science history. In this field, scholars have profited by resorting to analyses which combine intertextual connections with another set of elements also dear to literary studies, that of paratexts, as described by Gerard Genette. 
Indeed, for Science History, a growing concern with notions such as "text architecture", "textual segmentation" and "paratexts" and with how they may influence the reception and the understanding of a certain scientific account, taking also into consideration the materiality of books. As explained by Bretelle-Establet and Schmitt in their introductory chapter to an anthology on "pieces and parts in scientific texts",

[t]he metatextual traces left by textual actors, often translating their intentions, guide the reader in his/her interpretation of the text (putting, for exemple, chapter titles at the same level of structuration on the basis of the same layout, the same indentation or the same font). According to this linguistic perspective, all these traces left by the writer in his/her text do more than merely embellish: they are truly functional devices for the reader and cannot be taken for granted. (9)

At this point, there is an interesting intersection between Translation History and Science History which should be mentioned. Researchers in these two fields are working with methods and tools which question epistemological stances and blur the lines separating the various areas of knowledge. Certainly, the work with texts is the major underlying cause for this, not only because the blank page accepts combinations of concepts and ideas that do not necessarily obey any division regarding subject matters, but because texts are historical documents by their own right, obviously crucial sources for those whose main concern are books in general, translations and science (both of which are materialized especially as published written texts).

Texts should be understood not only as an expression of their authors' individual beliefs but they should also be seen as testimonies of a certain set of values which are valid when they were written. It is this historicity of written material left by authors, translators and scientists that can help us to understand 
how cultures influenced one another. As to translation, this has already been recognized by Portuguese literary scholar Gonçalves Rodrigues, who put together an amazing chronological account of all translations published in Portugal from 1495 to 1950. For him, the study of translations published by and for a given community would reveal, among other things, "the evolutive process of forms, genres and tastes", and the "the immediate or late penetration of ideas, styles, critical attitudes" (15).

Another significant parallel can be drawn between translation history and science history if one continues on this path of exploring what investigations in such fields can unveil. At this point, Peter Burke's take on the role of historians fits perfectly:

I [...] see historians as the guardians of the skeletons in the cupboard of the social memory [...]. There used to be an official called the 'Remembrancer'. The title was actually a euphemism for debt collector. The official's job was to remind people of what they would have liked to forget. One of the most important functions of the historian is to be a remembrancer. (110)

Translation and science historians' raison d'etre is to undo the erasure of foreign sources and cultural influences, which means reminding us that we are always in debt because nothing is originally ours. A web of words, knowledges, ideologies, techniques, and values defines us as individuals and cultures. For this paper, the purpose is to reveal a tiny part of this debt by exploring the contents of epigraphs and mottoes in scientific translations published in Portugal from 1798 to 1806. 


\section{Translations for the progress and greatness of the Portuguese empire}

At the end of the $18^{\text {th }}$ century, Portugal had already lost its place among the wealthiest nations of Europe. Even though she still had her colonies, Portugal was seen as a land lacking in progress and scientific development. It was this falling behind her rivals in the Americas and in the South Seas that led the Portuguese government to adopt an official progressive policy whose purpose was to promote advancement especially in areas considered strategic, such as agriculture, manufacture, and the fine arts. In this context, books, instruction, and translation were taken as essential.

Based on the enlightened notion that the nation's progress and happiness depended on instruction and on the acquisition of knowledge imported especially from France and England, the Portuguese Crown became the main patron of a system involving several Lisbon-based publishing houses, and many individual translators, printers, artists and other professionals in an effort to make great quantities of foreign books available in Portuguese (Curto; Oliveira Harden "Brasileiro tradutor").

One of the main figures of this movement was the Brazilianborn Friar José Mariano da Conceição Velloso, who was put in charge of the mission of publishing all material he thought useful for the improvement of the Portuguese Kingdom, especially its richer colony, Brazil. This man of letters had the power to decide which works should be translated, to hire translators, engravers, and other printing professionals/artists, and to administer a quasiofficial publishing house, the Casa do Arco do Cego, which ran only for two years (1799-1801) but managed to be involved in the publication of 84 books (translations and original books). Velloso was also a prolific translator, and his 10 -volume series " $\mathrm{O}$ Fazendeiro do Brazil" is proof of his obsession with presenting his nation the weapons necessary to win the battle against ignorance. Velloso was, therefore, behind many of the translations published 
within this context, either by doing the translation himself or by compiling and editing translations done by others.

The publications supervised by Velloso were the sources of the epigraphs and mottoes analysed here. The criteria for selecting the material involved the following: I) the epigraph or motto should be placed on the title page; II) it should come from a translated work done by a Brazilian-born translator. The result was a small but representative list of nine works, presented with short titles in Table 1 (detailed bibliographical data is given in the Works Cited section). They are all in line with Velloso and the Portuguese government preoccupation with products which had economic relevance.

Table 1 - Translations published within Luso-Brazilian Enlightenment and their epigraphs and mottoes. ${ }^{2}$

\begin{tabular}{|l|l|l|}
\hline Title of Book & $\begin{array}{l}\text { Motto / Epigraph } \\
\text { on Title page }\end{array}$ & English version \\
\hline $\begin{array}{l}\text { 1) O Fazendeiro do } \\
\text { Brazil, tomo II, parte } \\
\text { II (Beauvai Raiseau) } \\
\text { (on dyeing - Indigo } \\
\text { tree) }\end{array}$ & $\begin{array}{l}\text { Hyacinthum, Purpura, } \\
\text { Coccigera. Ex. Cap. xxv. }\end{array}$ & $\begin{array}{l}\text { (And this [is] the } \\
\text { offering which ye shall } \\
\text { take of them; gold, and } \\
\text { silver, and brass, 4. } \\
\text { And blue, and purple, } \\
\text { and scarlet, and fine } \\
\text { linen, and goats' [hair] } \\
\text { (King James Bible } \\
\text { Online, Ex. 25, 3-4) }\end{array}$ \\
\hline
\end{tabular}

${ }^{2}$ I thank Maria Harden, Theo Harden and Julio Monteiro for their translations from Latin and Dutch into English.

${ }^{3}$ For this epigraph, it seems that the source was mistakenly given as verse 1947 of the work of Gilbert Knowles, Materia medica botanica (1723). The passage quoted as an epigraph is in verse 1505 and reads as: "meritò hâc unâ satìs arbore felix dicenda est region; sparsas nam hinc omnibus oris orbis opes trahit as sese" (Knowles 1723). 


\begin{tabular}{|c|c|c|}
\hline $\begin{array}{l}\text { 2) O Fazendeiro do } \\
\text { Brazil, tomo III, } \\
\text { parte I (Velloso) (on } \\
\text { coffee) }\end{array}$ & $\begin{array}{l}\ldots \text { merito hac una Satis } \\
\text { arbore felix } \\
\text { Dicendo est region; } \\
\text { Sparsas nam hinc omnibus } \\
\text { oris Orbis opes trahit ad } \\
\text { sese. } \\
\text { Knowl. § } 1947^{3}\end{array}$ & $\begin{array}{l}\text { Due to the existence of } \\
\text { this tree, the region has } \\
\text { to be called fortunate. } \\
\text { By disseminating it from } \\
\text { here into other areas, } \\
\text { it will bring wealth to } \\
\text { those. }\end{array}$ \\
\hline $\begin{array}{l}\text { 3) O Fazendeiro do } \\
\text { Brazil, tomo III, } \\
\text { parte III (Velloso) } \\
\text { (on cocoa) }\end{array}$ & $\begin{array}{l}\text {... Quis potum Chocolatae } \\
\text { ne selt edutem? } \\
\text { Dat vegetum membris } \\
\text { habitum, floremque } \\
\text { Venustae } \\
\text { Purpureum Majestatis, dat } \\
\text { dulcia cordi } \\
\text { Lumina Laetitiae, nec forte } \\
\text { potentior alter } \\
\text { Lenè Ciere viros, Venerem } \\
\text { que accendere succus. } \\
\text { (Coul., 200) }\end{array}$ & $\begin{array}{l}\text { (For chocolate at once } \\
\text { is drink and food) Does } \\
\text { strength and vigour to } \\
\text { the limbs impart, makes } \\
\text { fresh the countenance } \\
\text { and chears the heart, in } \\
\text { Venus combat strangely } \\
\text { does excite the fainting } \\
\text { warriour to renew the } \\
\text { fight. (Abraham Cowley } \\
1668,1.880-885 \text { ) }\end{array}$ \\
\hline $\begin{array}{l}\text { 4) O Fazendeiro } \\
\text { do Brazil, tomo IV, } \\
\text { parte I (Velloso) (on } \\
\text { spices) }\end{array}$ & $\begin{array}{l}\text { Castilla reges ditat Peruma } \\
\text { Potosis, } \\
\text { Aurea Soffala fertur orena } \\
\text { Tago } \\
\text { Omnibus his venis } \\
\text { praferrem Caryophyllum, } \\
\text { Quem Liber Domini } \\
\text { manere Belga tenet. } \\
\text { Rumph. Lib. II. Cap. II, } \\
\text { 10. }\end{array}$ & $\begin{array}{l}\text { The Castillian crown } \\
\text { is proud of the rich } \\
\text { mountains of Peru, } \\
\text { The Portuguese flatter } \\
\text { themselves over the } \\
\text { sands of Sofala; } \\
\text { All men prefer the clove } \\
\text { from the Molucas, } \\
\text { Which God, our } \\
\text { Creator, gives freely to } \\
\text { the Dutch. }\end{array}$ \\
\hline $\begin{array}{l}\text { 5) O Fazendeiro } \\
\text { do Brazil, tomo V, } \\
\text { parte I (Velloso) (on } \\
\text { cordage) }\end{array}$ & $\begin{array}{l}\text { Ex lanis iugens illa } \\
\text { pannorum multitudo } \\
\text { elaboratur, alque Siadones } \\
\text { texunt, alias viliores, alias } \\
\text { pretiosissimas. Ex his } \\
\text { vestes illae Sacerdotibus } \\
\text { olim Aegypti gratissimae } \\
\text { parabantur. }\end{array}$ & $\begin{array}{l}\text { A great deal of these } \\
\text { cloths is made of woven } \\
\text { threads of wool, similar } \\
\text { to altar cloths. Some of } \\
\text { them are not valuable, } \\
\text { others are precious. } \\
\text { From the latter type the } \\
\text { robes of the Egyptian } \\
\text { priests were made }\end{array}$ \\
\hline
\end{tabular}




\begin{tabular}{|l|l|l|}
\hline $\begin{array}{l}\text { 6) Discurso Prático } \\
\text { acerca da Cultura } \\
\text { (..) do Canamo } \\
\text { (Nuvellone-Pergamo) } \\
\text { (on hemp) }\end{array}$ & $\begin{array}{l}\text { Jubet amor patrice, natura } \\
\text { juvat, sub namine crescit. }\end{array}$ & $\begin{array}{l}\text { The fatherland requires } \\
\text { it, nature supports it, } \\
\text { under your reign it will } \\
\text { grow }\end{array}$ \\
\hline $\begin{array}{l}\text { 7) Alographia } \\
\text { dos Alkalis Fixos } \\
\text { (1798) (on alkaline } \\
\text { substances) }\end{array}$ & $\begin{array}{l}\text { Ignari discant, ament } \\
\text { meminisse periti. }\end{array}$ & $\begin{array}{l}\text { Let the unlearned learn, } \\
\text { let the learned love to } \\
\text { remember }\end{array}$ \\
\hline $\begin{array}{l}\text { 8) Memoria sobre } \\
\text { (..) Adubos (Massac) } \\
\text { (on manure) }\end{array}$ & $\begin{array}{l}\text { Arida tantum. } \\
\text { Ne saturare simo pingui } \\
\text { pudeat sola, neve } \\
\text { Effaetos cinerem } \\
\text { immundum jactare per } \\
\text { agros. } \\
\text { Virg. Georg. Liv. I. }\end{array}$ & $\begin{array}{l}\text { "(rotation lightens the } \\
\text { labour) only scorn not } \\
\text { to soak the dry soil with } \\
\text { fattening dung, nor to } \\
\text { scatter grimy ashes over } \\
\text { the exhausted lands". } \\
\text { (Virgil "The Georgics" } \\
\text { 291) }\end{array}$ \\
\hline $\begin{array}{l}\text { 9) Tratado sobre o } \\
\text { Canamo } \text { (Marcandier) } \\
\text { (on hemp) }\end{array}$ & $\begin{array}{l}\text { Jubet amor patriæ, natura } \\
\text { juvat, sub namine crescit. }\end{array}$ & $\begin{array}{l}\text { The fatherland requires } \\
\text { it, nature supports it, } \\
\text { under your reign it will } \\
\text { grow. }\end{array}$ \\
\hline
\end{tabular}

Source: Oliveira Harden, "Brazilian translators in Portugal” (222-3)

\section{Epigraphs and mottoes, authors and books}

The quotations found in the title pages are mottoes and epigraphs in Latin. The use of these elements in Latin was a common feature of title pages during the 18th century, apparently more so in "works of ideas [rather] than of poetry" (Genette, 146), which is the case with the works published under Velloso's supervision.

Mottoes, as explained by Genette (144), are quotations used for more than one work, and they establish an intertextual link that helps to create a specific context of production and reception for these works, as it is done for publications within a series. With regard to the elements in Table 1, the sentence "Jubet amor patrie, 
natura juvat, sub nomine crescit”, which appears on items 6 and 9, is an example.

An epigraph, conversely, relates only to the book in which it appears, serving as a device to grab the readers' attention and to facilitate their understanding of the work. It provokes a certain curiosity in the readers and prepares them for the discursive strategies and references used by the author/translator throughout the text. Thus, the quotations in 1, 2, 3, 4, 5, 7, an 8 of Table 1 are epigraphs.4 According to Schmitt, they are of especial relevance for studies concerning the scientific literature of the Enlightenment, since they "throw light on the aims and audience of a given work" and are "invaluable tools in understanding the aims and status of a given book" (270).

Mottoes and epigraphs create an intertextual net which is supposedly shared with the readers, and, therefore, establish a rapport between those responsible for the written work (authors, publisher, and, in our case here, translators) and readers which makes the latter more willing to engage with the text. It is a textual device which invite those having their first contact with the work to become part of a group with a specific reading history, with certain values and purposes. Interestingly, they simultaneously have the illocutionary force of a declaration, because readers are made part of the selected congregation of those people who understand and accept the words in mottoes and epigraphs as theirs, and are brought into the intertextual network created by these paratextual elements.

In this sense, they can be interpreted as rhetorical mechanisms of captatio benevolentiae, which is aimed at winning the sympathy of an audience and getting the readership to excuse any possible failures in the thoughts or concepts within the work. In the case of translations, it is a technique known to be used as a way of asking readers to be more forgiving as to any mistake in the resulting text or disloyalty towards the original one.

${ }^{4}$ For this article, only epigraphs and mottoes placed on the title pages were considered. Please note that, for items 1 and 4 there were epigraphs on other parts of the books. 
The extracts shown in Table 1 vary in length but not exceeding four lines. They appear on title pages of translations by Friar Velloso and of translations accredited to him, with one exception, which is the one tagged as number 9, Tratado sobre o canamo, published in 1799, a translation by Martim Francisco Ribeiro de Andrade5 of Marcandier's 1758 Traité du Chambre. Although there is clear reference to Ribeiro de Andrade as the translator, the long (classic) title also mentions Velloso as publisher and, thus, responsible for the work. A common trait among the publications in Table 2 is a fundamental concern with their respective national economies, especially the role played by agriculture. The idea is not to promote idle, contemplative or politically revolutionary knowledge, but to spread information that can be sensibly applied for the common good and progress of the kingdom.

The second element uniting all textual agents (author, translator, the Portuguese Prince, editor, and readers) is obviously the familiarity with Latin. According to Genette, the epigraph is a sign of culture, or a "password of intellectuality" (160). It is an indication of whom the author, the publisher and here, the translator, consider as part of their group. With the epigraph (and certainly also with mottoes), the author "chooses his peers and thus his place in the pantheon" (160) of cultural tradition. Here, the choice of texts in Latin and the authors quoted indicate that the publications should be perceived as popular enough to reach a broader audience, but should still be seen as coming from educated men (authors, translators, publisher, and the prince) whose background included proficiency in classical languages (Latin and Greek) and familiarity with classical works of literature and of sciences.

It could be argued that adding mottoes and epigraphs in Latin to title pages of books aimed at farmers, such as most of the works

\footnotetext{
${ }^{5}$ Martim Francisco Ribeiro de Andrada Machado was one of the Irmãos Andrada (Andrada brothers), together with Antonio Carlos Ribeiro de Andrada Machado and José Bonifácio de Andrada e Silva, three very influential political figures in Brazil at the beginning of the 19th century, the three being involved in the independence process and in the government of D. Pedro I (first ruler of independent Brazil).
} 
listed in Table 1, is not an obvious choice. Were these intended audience familiar enough with Latin as to be able to understand the quotations? Unfortunately, research on the works published within the Luso-Brazilian Enlightenment have not focused on their reception. What can be inferred is that the "farmer" (Fazendeiro) meant to be reading the works was the typical land owner, who belonged to the aristocratic elite which would send their sons to Coimbra for their education. They would therefore most likely be proficient in Latin and French (Wyler). A second reason for the use of quotations in Latin can be found in the fact that Latin was the language of important previous publications in medicine and botany, for example, and that would vow for the relevance of the titles presented to the readers of works in Portuguese. Similarly, the prestige of authors such as Virgil and Horace, as well as Cowley6, even if quoted in Latin, was such that mentioning their names would probably be enough to activate social and interpretative networks in the readers' minds.

The motto "Jubet amor patriæ, natura juvat, sub numine crescit" (the love for the fatherland requires it, nature supports it, under your reign it will grow) was used by Velloso in several of his publications, appearing either on the title page (more commonly) or on the following page, before the dedication, as happens with his compilation Quinografia portuguesa, of 1799, in which his translations of pseudo-scientific accounts are accompanied by his own texts about the genus cinchona, broadly known in Portuguese as Quina and famous for its medicinal uses. The sentence in Latin encompasses important elements that marked Velloso's editorial project, notions such as loyalty for the father land, concern with nature and knowledge, and religious belief in divine protection.

This perfect fit was not, however, an original idea of the Friar's. The same sentence appears in various other publications in the 18th century, in texts published in the Netherlands and in Germany, for instance. The Latin quotation appears on the title pages of the

${ }^{6}$ Abraham Cowley was a famous British poet of the $17^{\text {th }}$ century. 
Journal de commerce, published in Brussels in 1761, and of the Allgemeines oeconomisches Forst-Magazin, published in Frankfurt and Leipzig in 17677, as shown in Table 2.

Table 2 - Title pages of a) Tratado sobre o Canamo (Marcandier 1799), b) Journal de Commerce (1761), and c) Allgemeines Oeconomisches Forst Magazin (Stahls, 1767). In green, the quotation "Jubet amor patriæ, natura juvat, sub numine crescit".

\begin{tabular}{|c|c|c|}
\hline a) & b) & c) \\
\hline 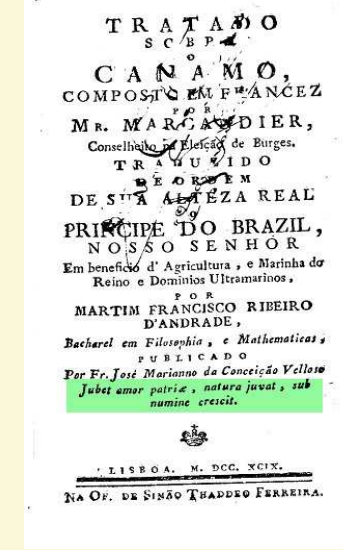 & 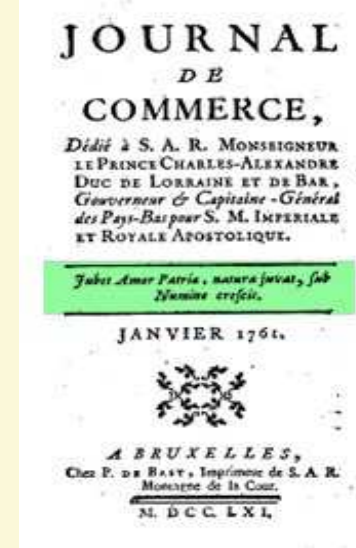 & 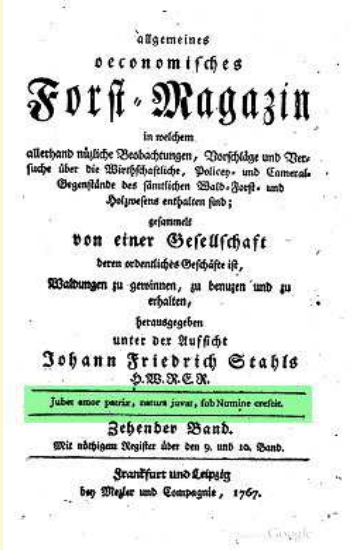 \\
\hline
\end{tabular}

Source: Oliveira Harden, "Brazilian translators in Portugal" (225)

Among the authors quoted in the epigraphs in Table 1 are God himself, Horace and Virgil, all sources whose authority was well established at the time. This is certainly intended to give credibility to Velloso's publications, besides also serving to reveal an association to the Catholic tradition and classical literature. There are also quotations from respected works in medicine and natural sciences, such as in $O$ Fazendeiro do Brazil tomo III, parte I (Velloso), in

\footnotetext{
${ }^{7}$ Both these periodicals circulated for several years, and the dates mentioned refer solely to the issues given as examples.
} 
which Friar Velloso, as the work's editor and translator, includes a passage taken from Materia medica botanica, written by British botanist and poet Gilbert Knowles and published in 1723 with an epigraph from Virgil's Aeneid on its title page. The epigraph, right on top of the indication of who authored the work, reads: "Scire potestates Herbarum, usumque Medendi Maluit \& mutas agitare inglorious artes" (Vir. Æneid 12. V. 396). In English, this verse was rendered as " $[\mathrm{He}]$ chose rather to know the virtues of herbs and the practice of healing, and to ply, inglorious, the silent arts" by Rushton Fairclough, in Virgil (324).

In another example, the title page of $O$ Fazendeiro do Brazil tomo VI, parte I (Velloso), of which spices are the subject (more specifically clove and nutmeg), the epigraph comes from a work included in the publication itself. The source was the gigantic Herbarium amboinense, published in a bilingual edition (Dutch and Latin) in 1741 and written by Georg Eberhard Rumphius and Joannes Burmannus (the editor and translator into Dutch). Rumphius was a German botanist employed by the Dutch East Indies Company, and his Herbarium amboinense is a description, with illustrations and nomenclature, of the plant species native of Amboina, today's Indonesia. Rumphius' was an influential work in botany in the 18th century, and was certainly seen as a high point in the collection of texts translated. Three chapters of the Herbarium were translated and included in Velloso's edition on spices.

In all cases, more than evoking a certain disposition in the readers, the epigraphs have the effect of justifying the translation, the publication and ultimately the interest in the topic. At a time when European powers warred to keep or expand their dominion over areas producing cloves and nutmeg, the concern that led to the translation of over 300 pages was more than understandable. The epigraph taken from Rumphius's Herbarium mentions how the Dutch dominated this very profitable market, comparable to the riches brought by the Spanish-American gold and the Portuguese territories in Africa, and given to them by God: 
Castilla reges ditat Peruma Potosis, Aurea Soffala fertur orena Tago

Omnibus his venis praferrem Caryophyllum,

Quem Liber Domini manere Belga tenet.

(The Castillian crown is proud of the rich mountains of Peru,

The Portuguese flatter themselves over the sands of Sofala.

All men prefer the clove from the Molucas,

Which God, our Creator, gives freely to the Dutch.)

God's word is quoted in the in the publication on dyeing and the indigo tree, O Fazendeiro do Brazil, tomo II, parte II (Beauvais Raiseau). The book has a title page with a quotation from the Exodus: "Hyacinthum, Purpura, Coccigera. Ex. Cap. xxv. V. 17 ". Velloso, as the editor and translator, wants to highlight the preciousness of dye-stuffs by quoting the instructions given in the Bible regarding the offerings that should be brought to God. The Vulgate is the source used in Velloso's epigraph, the Latin text having maintained the relation between the word 'hyacinth' and the colour blue (deep purplish blue), as well as the cochineal ('coccigera') and the colour carmine. Velloso returns to the theme of the epigraph in his dedication:

The fabrication of dyes of the colours blue, purple and scarlet are as worthy of the high attention of Y.R.H, and of your immediate protection as could, and should be gold, silver \&c., for all of them are equally possessions which come from the Sovereignty that the Almighty conferred onto Y.R.H. (Velloso "Dedicatória-Prefácio" vi) ${ }^{8}$

${ }^{8}$ In the original Portuguese: O fabrico do azul, o da purpura, o da cochonilha, são tão dignos da alta contemplação de V. A. R., e da sua immediata protecção, como podem, e devem ser o ouro, a prata \&C., pois huns e outros são igualmente pertences da Soberania, que o TodoPoderoso conferio na Pessoa de V. A. R. 
He goes on to add information on the relationship between the colour blue and the Bible:

The colour blue is so cherished in the Divine Letters, that in Exodus alone it is repeated thirty times, under the word Thecheleth, which the vulgate rendered as hyacinthinum, due to the colour blue of the Hyacinth. (vii) 9

The return in the prefatorial dedication to the theme evoked with the epigraph on the title page establishes a connection between the two kinds of paratexts, and gives reason to consider the epigraph (and the motto) as a shorter and more direct version of the preface, or the "preface in embryo" (Henige 76), as it prepares the way not only to the text itself, but also to the author's (and here, the translator's and publisher's) way of thinking, in terms of intertextuality and ideological affinities.

\section{Final considerations}

I argue in this article that epigraphs and mottoes should be deemed as valuable sources of information in research projects in which the aim is to place published works within a certain intellectual or scientific movement or within a given historical context. As signs of the mediation exercised by translators, editors, and publishers on the relationship between text and readers, they disclose allegiances, forge or flaunt intellectual fellowships, reminding us these textual agents are first and foremost readers themselves. As such, they belong to an intertextual web, which, if recognized by translation and science historians, can shed light on their editorial choices, for example.

In the case of the publications produced under Velloso's guidance, there is a clear alignment to authors and works concerned with the

\footnotetext{
${ }^{9}$ In Portuguese: A côr azul he de tanta estimação nas Divinas Letras, que só no Exodo se acha repetida trinta vezes, debaixo da palavra Thecheleth que a vulgata verte hyacinthinum, pela côr azul do Jacintho.
} 
growing of primary agricultural products of special relevance at the time, such as spices, hemp, and plants used for dyeing, with the devotion to the motherland, and with the application of knowledge on biology and medicine. As such, they helped to place the LusoPortuguese translators and scientists within the great intertextual network of the Enlightenment known as the Republic of Letters.

\section{References}

Beauvais Raiseau (Beauvais-Raseau). O Fazendeiro do Brazil: Cultivador. (...). Tomo II. Tinturaria. Parte II. Cultura da Indigoeira, e Extracção da sua Fecula. Translated by J. M. da C. Velloso. Lisboa: Off. Simão Thaddeo Ferreira, 1800.

Bretelle-Establet, Florence, and Stéphane Schmitt. "Introduction." Pieces and Parts in Scientific Texts, edited by Florernce Bretelle-Establet, and Stéphane Schmitt. Springer, (2018): 3-17.

Burke, Peter. "History as Social Memory." Memory, History, Culture and the Mind, edited by Thomas Butler, Basil Blackwell, (1989): 97-114.

Curto, D. R. (1999) 'D. Rodrigo de Souza Coutinho e a Casa Literária do Arco do Cego'. M. F. Campos (org.) A Casa Literária do Arco do Cego: Bicentenário. Lisboa: Biblioteca Nacional e Imprensa Nacional, Casa da Moeda, (1999): 15-49.

Genette, Gerard. Paratexts: Thresholds of Interpretation. Trans. Jane E. Lewin. Cambridge - New York: Cambridge University Press, 1997.

Gonçalves Rodrigues, Antônio A. A Tradução em Portugal: Tentativa de Resenha Cronológica das Traduções Impressas em Língua Portuguesa Excluindo o Brasil de 1495 a 1950. Lisboa: Imprensa Nacional - Casa da Moeda, 1992. 
Henige, David. "Being Fair to the Hounds: The Function and Practice of Annotation, II". History in Africa, 29, 2002, 63-88.

Journal de Commerce. Volume 18. Bruxelles: Chez P. de Bast, 1761.

Knowles, Gilbert. Materia Medica Botanica (...). Londini: Guil. Bowyer, 1723.

Kristeva, Julia. "Word, Dialogue and Novel". The Kristeva Reader, edited by Toril Moi. New York: Columbia University Press, 1986.

Marcandier, M. Tratado Sobre o Canamo, Composto em Francez por Mr. Mercandier, (...). Translated by M. F. R. de Andrade. Lisboa: Off. de Simão Thaddeo Ferreira, 1799.

. Traité du chanvre. Paris: Chez Nyon, 1758.

Massac, Pierre L.-R. Memoria sobre a Qualidade, e sobre o Emprego dos Adubos, ou Estrumes. Translated by J. M. da C. Velloso. Lisboa: Typographia Chalcographica, Typoplastica, e Litteraria do Arco do Cego, 1801.

Nuvellone-Pergamo, Giuseppe. Discurso Prático sobre a Cultura, Maceração e Preparação do Canamo (...). Translated by J. M. da C. Velloso. Lisboa: Off. de Simão Thaddeo Ferreira, 1799.

Oliveira Harden, Alessandra R. "Brasileiro tradutor e/ou traidor: Frei José Mariano da Conceição Veloso". Cadernos de Tradução , 1.23 (2009): 131-148.

. Brazilian translators in Portugal 1785-1808: ambivalent men of science. Vol. I: 401 p., Vol. 2: 211 p. Dublin: University College Dublin. Doctorate Thesis. Hispanic and Lusophone Studies, School of Languages and Literatures, University College Dublin, Dublin-Irlanda, 2010.

. "Tradução, história e o Iluminismo luso-brasileiro: a Casa Tipográfica

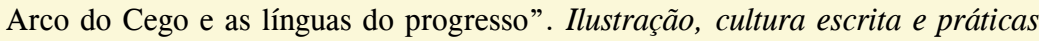
culturais e educativas. Edited by Antonio Cesar de Almeida Santos, Estúdio Texto, 2016, 107-129. 
Rumphius, Georg Eberhard. Herbarium amboinense: plurimas conplectens arbores, frutices, herbas, plantas terrestres \& aquaticas (...). Edited and translated by Joannes Burmannus. Pars secunda. Amstelaedami, 1741.

Schmitt, Stéphane. "Epigraphs as Parts of Text in Natural History Books in the Eighteenth Century: Between Intertextuality and the Architecture of the Book." Pieces and Parts in Scientific Texts, edited by Florernce Bretelle-Establet, and Stéphane Schmitt. Springer, (2018): 3-17.

Stahls, Johann F. (hrsg.). Allgemeines Oeconomisches Forst-Magazin in welchem allerhand nuzliche Beobachtungen (etc.). Zehender Band (etc.). Frankfurt Leipzig: Mezler und Compagnie, 1767.

The Bible. King James Version Standard Online. www.kingjamesbibleonline.org/ Exodus-Chapter-25/. Accessed 20 June 2018.

. The Latin Vulgata. www.biblestudytools.com/vul/exodus/25.html. Accessed 20 June 2018.

Velloso, José M. da C. Quinografia portuguesa ou Collecção de varias Memorias sobre vinte e duas especies de quinas, (...) por Fr. José Mariano Velloso (...). Lisboa: Offic. de João Procopio Correa da Silva, 1799.

. 'Dedicatória-Prefácio'. Beauvais Raiseau (Beauvais-Raseau). $O$ Fazendeiro do Brazil: Cultivador (...). Tomo II. Tinturaria. Parte II. Cultura da Indigoeira, e Extração da sua Fecula. Translated by J. M. da C. Velloso. Lisboa: Off. Simão Thaddeo Ferreira, 1800

. (editor and translator). O Fazendeiro do Brazil: Cultivado. (...) Colligido de Memorias Estrangeiras (...). Tomo III. Bebidas Alimentosas. Parte I. Lisboa: Off. Simão Thaddeo Ferreira, 1800.

. (editor and translator). O Fazendeiro do Brazil: Cultivador. (...) Tomo III. Bebidas Alimentosas. Cacao. Parte III. Lisboa: Impressam Regia, 1805.

. (1805b) (editor and translator) O Fazendeiro do Brazil: Cultivador. (...) $\overline{\text { Tomo IV }}$. Especierias. Parte I. Lisboa: Impressam Regia, 1805. 
. (editor and translator). O Fazendeiro do Brazil: Cultivador. (...) Tomo V. Filatura. Parte I. Lisboa: Impressam Regia, 1806.

Virgil. The Georgics of Virgil. Translated by J. W. MacKail. New York: Modern Library, 1934.

. Virgil in Two Volumes. Translated and edited by R. Fairclough. (Rev. ed.) London: William Heinemann; Cambridge (MA): Harvard University Press, 1960 .

Wyler, Lia. Línguas, Poetas e Bacharéis: Uma Crônica da Tradução no Brasil. Rio de Janeiro: Ed. Rocco, 2003.

Recebido em: $15 / 04 / 2018$

Aceito em: 31/07/2018 Publicado em setembro de 2018

Alessandra O. Harden. E-mail: oliveira.ales@gmail.com ORCID: https://orcid.org/0000-0003-2473-057X 